\title{
Marketing performance of subsidiaries operating abroad: An integrative model
}

\author{
Roberto Flores Falcão, Gilmar Masiero e Marcos Campomar ${ }^{1}$ \\ Faculdade de Economia, Administração e Contabilidade da Universidade de São Paulo, FEA-USP/SP, São Paulo/SP, Brasil
}

ARTICLE DETAILS
Article history:
Received 30 May 2016
Accepted 08 November 2016
Available online in 30 December 2016
Double Blind Review System
Scientific Editor
Ilan Avrichir

Keywords:

International Marketing

Marketing Performance

Subsidiaries

Integrative Model

\begin{abstract}
In the internationalization process firms face challenges in order to be successful, such as enabling knowledge transfer, finding the optimum balance between standardizing/adapting their marketing strategies, determining the strength of external networks, and deciding degrees of reverse innovation. Research on knowledge transfer in multinational firms has grown considerably over the last 15 years, but still little is known about its impact on the marketing performance of subsidiaries. The majority of the investigations carried out analyze knowledge transfer but not its interrelationships with the performance of subsidiaries. Several other studies evaluate the standardization/adaptation decision, but do not take into consideration issues such as operational environments or psychic distance. To fill this gap we review 70 articles published in top-tier peer-reviewed international and national journals in the field of international business and international marketing. From this review we build up a framework for the development of an integrative and explanatory theoretical model of the marketing performance of subsidiaries operating abroad with fifteen propositions. In this paper we present a literature review and model that will be empirically tested after gathering information to form a reliable database about the performance of multinationals.
\end{abstract}

(C) 2016 Internext | ESPM. All rights reserved!

\section{Introduction}

Firms can choose between entering the global competition or remaining restrict to their local positions. However, it must be emphasized that the survival of those who opt for a strictly local strategy is limited (Ramos, 2011), not only because of eventual market saturation, but mainly because such firms are not abreast of new and important technologies and knowledge. This process of catch-up with the best practices in the management field happens when firms internationalize their activities. The relationship between marketing strategies and performance has been well documented and has a variety of approaches (Cavusgil; Zou, 1994; Menon; Bharadwaj; Adidam; Edison, 1999; Matsuno; Mentzer, 2000; Vorhies; Morgan, 2003; Reinartz; Krafft; Hoyer, 2004; Rust; Lemon; Zeithaml, 2004; Baker; Sinkula, 2005). However, most papers focus on a specific entry mode, such as the investigation by Dalmoro (2010).
Broader studies on the antecedents of the marketing performance of subsidiaries operating abroad are meager. Therefore, despite the amount of papers on the subject, international performance still represents a hot topic in terms of research in International Business (Carpes; Velter; Scherer; Lütz, 2010).

Although there is a considerable number of studies analyzing and formulating models of internationalization, almost all focused on MNCs without addressing and considering the complexity of relationship networks (Rugman; Verbeke; Nguyen, 2011). Also noteworthy is a critique related to more traditional models due to their inability to present and evaluate background business dynamics. They are static models that do not incorporate environment turbulence (Ramamurti, 2012). Networks represent an important issue for marketing analysis, in which the performance of an organization 
is directly related to its ability to adapt and respond to markets they operate in (Lambin, 2000; Ferrell; Hartline, 2009). In international marketing, this mindset is very similar.

The existence of friendly and effective mechanisms of efficient and dynamic models that enable a faster evaluation of the performance of each foreign unit is increasingly relevant. Presence in foreign markets can occur in various forms and, depending on the business environment, an organization may need to relocate its local operation. This is what happened to AMBEV in 2013, for example. At the time, the firm decided to close its unit in Venezuela after realizing that the local dynamics were unsustainable; its products, however, continued to be offered through its network (AMBEV Closes Factory..., 2013). The case of Nestlé and Danone also illustrates the importance of properly monitoring environments. Because of cultural differences and the liability of outsidership (Rugman et al., 2011), both companies chose to close factories in China in 2011 (Domingues, 2011).

Thus, this study aims to identify the key environmental variables described in International Business and International Marketing literature and proposes a theoretical, integrative, and explanatory model for the marketing performance of subsidiaries operating abroad. The model developed incorporates the dynamics of the environment and the issue of organizational learning, and can be applied to large and small organizations - even franchise chains can benefit from it. Franchise chains such as Arby's and KFC, for example, were unable to properly analyze the Brazilian market before settling in the country. They did not achieve satisfactory results and ended their operations in Brazil after massive investments had been made (Naves, 1999).

The model is presented after a careful selection and review of previous literature on the concepts and theories described in articles published in top-tier peer-reviewed academic journals. Generally, the research results published in top journals represent validated knowledge and have great impact on the academic community. Our desk research focused on journals with an h-index greater than or equal to 60 . We also supported our selection on the Qualis (Sucupira) classification-a Brazilian system for qualifying academic journals - seeking " $A$ " journals. We included, for example, the Journal of International Business Studies, the Journal of
International Marketing, the International Business Review, the Journal of International Management, and the Revista de Administração da USP (Management Journal of the University of Sao Paulo).

It is important to highlight that this article is not intended to explain the reasons for firm internationalization, to discuss entry modes, or to analyze the decision on where to operate. Our main goal is to present an integrative new model of the marketing performance of subsidiaries operating abroad. In the following section, we present a literature review on the internationalization of firms and international marketing performance as well as their antecedents in order to summarize our constructs and modeling. In subsequent sections, based on the literature, we elaborate and justify our propositions, theoretical model, and scales. Final remarks are also presented that stress the necessity of testing the model.

\section{Literature review}

This chapter briefly discusses the main theories and concepts relevant to the development of the integrative model that is presented below.

\subsection{Internationalization of firms}

Given the hypercompetitive environment of the twenty-first century, firms need to search for new forms of management and focus on intangible assets such as the development of knowledge and skills. In this sense, the role of subsidiaries gains importance as a source of information and new technologies, and local embeddedness becomes a relevant issue for companies when better understanding and exploiting local opportunities (Schlegelmilch; Chini, 2003; Oliveira, 2009).

Several models and theories explain the internationalization process of firms. Some are ruled by Economics, guided by the option of foreign direct investment (FDI) in spite of relying only on imports and exports to sell products and purchase inputs in other countries. Others from Business Administration focus more on the role and perspective of managers. However, most models are static, do not incorporate market dynamics, nor do they facilitate an understanding of the marketing performance of subsidiaries, which is the aim of this paper.

The development of the propositions that were used for the construction of the integrative 
theoretical model presented in this study has incorporated various concepts and theories, such as: i) the advantages of ownership and location by Dunning (1980, 1988, 1993); ii) operation characteristics - Hoftede's (1980) concept of psychic distance; iii) product lifecycle by Vernon (1979); and iv) Polanyi's (1944) local embeddedness. Recent studies on the subject of international marketing performance, internationalization of firms, and the role of subsidiaries were also analyzed. The proposal herein was developed in order to measure and evaluate international marketing performance of MNCs regardless of entry mode strategies or other marketing decisions.

\subsection{International marketing performance and its antecedents}

From an economic perspective, globalization can be interpreted as the interaction of three processes: i) the significant expansion on international flows of goods, services, and capital; ii) increased competition in international markets; and iii) greater integration among national economic systems (Cateora; Graham, 1999). Facing this perspective, the main challenge in an internationalized market is the development of appropriate strategic planning that is consistent with the interdependence and unification of the global economy.

While domestic marketing involves manipulating only controllable variables (i.e., product, price, place, and promotion) and monitoring uncontrollable variables (e.g., economic, competitive, cultural, and legal environments), international marketing involves dealing with several markets in which controllable and uncontrollable variables also vary between themselves (Philips; Doole; Lowe, 1994). The lack of international marketing tools, according to Pipkin (2005), is one of the aspects responsible for the failure of organizations in foreign markets. Strategic planning is extremely important for firms to seize opportunities in a globalized environment. From a diagnosis of firm features and capabilities, an organization willing to work internationally needs a strategy compatible with the environment.

Grewal, Iyer, Kamakura, Mehrotra, and Sharma (2009) state that prior literature addresses the strategy-performance link in International Business according to four perspectives: dynamic capability, standardization, configuration-coordination, and integration-responsive (Luo, 2002; Zou; Cavusgil,
2002). Each perspective yields insights into assessments of global marketing performance and contributes to the development of market creation and market yield processes as a basis for evaluating subsidiary performance. Dynamic capability calls for the building and leveraging of capabilities across the MNC subsidiary network (Luo, 2002), and thus performance assessment involves creation-oriented and yield/exploitation processes. The standardization perspective entreats MNCs to seek economies of scale by standardizing their marketing activities across subsidiaries and adapting marketing strategy to relevant environmental diferences (Syzmanski; Bharadwaj; Varadarajan, 1993).

Within the field of international marketing, the debate over the extent of standardization or adaptation has occupied a significant part of past research. Several researchers concentrated their analysis on the relationship between firm marketing performance and the decision to adapt/standardize (Quester; Conduit, 1996; Theodosiou; Leonidou, 2003; Xu; Cavusgil; White, 2006; Sousa; Lengler, 2009; Vrontis; Thrassou; Lamprianou, 2009; Schmid; Kotulla, 2011). Supporters of standardization of the marketing mix stipulate that consumers' needs, wants, and requirements do not vary significantly across markets or nations and argue that this strategy enables economies of scale (Fatt, 1967; Levitt, 1983; YIP, 1996). Furthermore, different advertisements from different countries might create confusion amongst consumers (Backhaus; Van Doorn, 2007). On the other hand, proponents of adaptation stress the difficulties in using a standardized approach and its lack of potential local responsiveness (Kashani, 1989; Thrassou; Vrontis, 2006). Recent studies try to determine a balance between both approaches-a coexistence, establishing a complex interrelationship in the same firm(Kitchen, 2003; Vrontis, 2003; Soufani; Vrontis; Poutziouris, 2006).

Another issue that has long been studied is the relationship between marketing performance and decisions about the level of centralization (Brook, 1984; Gates; Egelhoff, 1986; Birkinshaw; Hood; Jonsson, 1998; Taggart; Hood, 1999; Vachani, 1999; Bowman; Duncan; Weir, 2000; Young; Tavares, 2004; Homburg; Prigge, 2014). Integration-responsive (Zou; Cavusgil, 2002) and configuration-coordination (Bartlett; Ghoshal, 1989; Craig; Douglas, 2000) perspectives suggest the need to leverage locationspecific advantages and take explicit account of firmand country-specific advantages enjoyed by each 
subsidiary while coordinating activities across subsidiaries in order to gain relevant synergies and control location-specific advantages and disadvantages.

Subsidiary autonomy represents an important variable in terms of marketing performance as well (Homburg; Prigge, 2014). However, Birkinshaw, Holm, Thilenius, and Arvidsson (2000, p. 321)believe that "Where the subsidiary desires autonomy, headquarters prefer control . . . and where the subsidiary is acting primarily in the interests of the local business, headquarters are far more concerned about the MNC's worldwide profitability." Moreover, although research has acknowledged the application of some headquarters' control over marketing decisions as vital to ensuring strategic alignment with subsidiary decisions (Luo, 2001), headquarter managers should still be aware that the more control they exert over marketing decisions within subsidiaries, the greater the subsidiaries' desire for autonomy will be (Homburg; Prigge, 2014).

Regardless of the importance of such issues, none of the models proposed by the authors take into account the impact of other variables simultaneously. In this sense, the proposals may fail to incorporate aspects that directly influence marketing performance as well as analyze the interrelationship between variables. The model we propose could reduce such flaws.

\subsection{Constructs and modeling}

Townsend and Ashby (1984) state that the measurement concept is related to the process of assigning numbers to objects in a way that empirical qualitative relationships between the objects are reflected by numbers as a property of the numeral system. Being so, the first step in proposing a model is the definition of constructs whose relationships we intend to evaluate (Hair; Black; Babin; Anderson, 2010).

An aspect emphasized by Hair et al. (2010) and Tabachnick and Fidell (2007) is that all models should be supported by theory. The theoretical basis is a necessary condition for determining relationships and causality, which can be determined later through statistical analysis (e.g., confirmatory factor analysis).It is noteworthy that any external influence on the dependent variable in question affects the supposed relationship of cause and effect investigated. Thus, causality verification in the social sciences can be reckless, leading to inappropriate conclusions or the determination of spurious relationships. As it is not possible to test all possible alternative explanations, it is impossible to completely eliminate the argument of spurious relationship (Tabachnick; Fidell, 2007). Still, according to the authors, the researcher can increase the reliability of the relations studied through a broad literature review.

\section{Propositions and theoretical model}

The critical first step in the development of the scales is to specify the domain of each construct (Churchill, 1979; Martin; Eroglu, 1993). The researcher must be exact in delineating what is included in the definition and what is excluded. In our study, this step involves a comprehensive review of literature related to marketing performance as well as the $\mathrm{HQ}$-subsidiary relationship and knowledge flow. The review also included literature on scale development. Along with the above studies, an interdisciplinary review of literature (e.g., international business, political sciences, economics, and sociology) resulted in the identification of 18 relevant dimensions. From this point, a second desk research was carried out in order to seek the definitions of each construct and possible scales to measure them. By doing this, we gathered all dimensions into 10 constructs and elicited 15 propositions, integrating different existing models.

Although there is a large number of relationships, theory corroborates all of them. The disregard of any of the propositions-by exclusion or groupingwithout the proper application of statistical tests may represent a loss of reliability or power for the proposed model.

It is noteworthy that the latent variables were measured by reflective indicators. As defined by psychometry, reflective indicators are those which are explained by the constructs (BABIN; HAIR JR; Boles, 2008), while the formation indicators explain the construct, without any correlation between them being expected (Jarvis; Mackenzie; Podsakoff, 2003; Diamantopoulos; Siguaw, 2006; Coltman; Devinney; Midgley; Venaik, 2008). The model is presented in Figure 1.

Discussion and application of hierarchical constructs, or multidimensional constructs, are often limited to a second order hierarchical structure, and can be defined as constructs involving more than one dimension (Edwards, 2001; Jarvis et al., 2003; 
Netemeyer; Bearden; Sharma, 2003; Mackenzie; Podsakoff; Jarvis, 2005). As such, they can be distinguished from unidimensional constructs, which are characterized by a single underlying dimension (Netemeyer et al., 2003). The utility of hierarchical construct models is based on a number of theoretical and empirical grounds (Edwards, 2001). Proponents of the use of higher-order constructs have argued that they allow for more theoretical parsimony and reduce model complexity (Edwards, 2001; Mackenzie et al., 2005).

\subsection{Propositions and theoretical basis}

P1: the greater the local advantages where subsidiaries operate, the more important the quality of the relationship between the parent company and its subsidiaries (and the strength of the internal network) is.

Several authors discuss the importance of subsidiaries in terms of marketing performance. A growing numbers of studies agree that the subsidiary can offer strategic benefits and advantages to the firm (Ramamurti, 2009, 2012; Melo; Borini; Oliveira Jr; Parente, 2015). Such advantages can only be exploited if the quality of the relationship between the $\mathrm{HQ}$ and subsidiary is good (i.e., a strong internal network). A study by Holm and Pedersen (2000) points out this issue.

P2: the greater the distance (between the home country and the location of operation), the more important the quality of the relationship between the parent company and its subsidiaries (and the strength of the internal network) is:

Distance-related research is one of the most important streams within international business (IB) (Zaheer; Shomakre; Nachum, 2012). Hutzschenreuter, Kleindienst, and Lange (2015) propose that distance typically refers to the extent of differences between country pairs. Literature relates distance to four different dimensions: culture, administration, geography, and economy (Ghemawat, 2001). Culture is the most discussed dimension in the literature, giving the studies of Hofstede prominency. The effects of distance are diverse: i) it can disturb the flow of information between the firm and the market (Johanson; Wiedersheim-Paul, 1975); and ii) it introduces friction (Shenkar; Luo; Yeheskel, 2008) and complexity (Vermeulen; Barkema, 2002) in cross-border activities. The concept of distance first appeared in
Johnson and Vahlne's (1977) seminal article and was spread worldwide by Hofstede's studies. In 1988, Kogut and Singh proposed a new perspective on the subject. However, despite 40 years of study, there still is ambiguity and a lack of clarity in regards to: i) the dimensions of distance, and ii) the measurement of distance (Hutzschenreuter et al., 2015). Even so IB researchers agree that it represents an important construct for the analysis of MNC activities and performance and that the quality of the relation between $\mathrm{HQ}$ and subsidiaries should be related to it (Sousa; Lengler, 2009).

P3: The greater the distance (between the home country and location of operation), the more important it is for the subsidiary to develop a strong external network.

The greater the distance-cultural, economic, or geographic-between the home country and the location of the subsidiary, the bigger the obstacles that a firm has to deal with in order to become locally competitive will be. Thus, it is important to maintain a good relationship between $\mathrm{HQ}$ and subsidiaries and to strengthen the internal network of the MNC (Sousa; Lengler, 2009; Hutzschenreuter et al., 2015).

P4: The greater the dynamics/turbulence where the subsidiary operates, the more important the knowledge flow between the parent company and its subsidiaries (and within subsidiaries) is.

Market turbulence refers to the rate of change in customer preferences and competitive actions in a host country (Cui; Griffith; Cavusgil; Dabic, 2006; Lee; Chen; Kim; Johnson, 2008). It determines how foreign firms interpret local market information (and knowledge generated from their major competitors and customers) and then acts on it, exploiting any opportunities presented in such unpredictable environmental changes. According to the degree of local uncertainty (political, legal, economic a.s.f.), MNCs need constant exchange information and to share decisions in order to maximize their marketing performance (Birkinshaw et al., 1998). Knowledge management becomes more important as well (Schlegelmilch; Chini, 2003) because companies learn, and the sharing of previous experiences minimizes risks and speeds up decision-making (Park; Vertinsky; Becerra, 2013).

P5: The greater the dynamics/turbulence where the subsidiary operates, the more important the quality of the relationship between the parent company and its subsidiaries (and the strength of the internal network) is. 
As reported by Birkinshaw et al. (1998) and Borini (2010), the greater the dynamism of the competitive environment, the greater the probability that the subsidiary becomes strategically important. Thus, the quality of the $\mathrm{HQ}$-subsidiary relationship is directly related to local dynamics/ turbulence. It is also important for MNCs as a way of avoiding the loss of the subsidiary (Oliveira, 2009). Studies by Schlegelmilch and Chini (2003) and Park et al. (2013) have also discussed the importance of the relationship between $\mathrm{HQ}$ and subsidiary in relation to local turbulence.

P6: Distance has a direct influence on the standardizing/adapting decision.

According to the amount of difference between the home country and the location of the operations, a subsidiary may benefit more from standardized marketing decisions (Quester; Conduit, 1996; Costa, 1998; Ambos; Ambos; Schlegelmilch, 2006). Several studies have shown that each situation needs to be carefully analyzed so that the MNC can benefit the most from local opportunities and maximinze local responsiveness. Jain (1989) proposes a framework for determining the extent of standardization of marketing programs.

P7: The better the quality of the relationship between the parent company and its subsidiaries (strength of the internal network), the more autonomy is granted to them.

Quester and Conduit (1996) conclude that there is no correlation between standardization and the centralization of decisions. Thus, it is possible for a MNC to have a strong internal network and some centralized decisions and offer a high degree of autonomy to its subsidiaries. Other studies, such as the paper by Gates and Egelhoff (1986) and Birkinshaw et al. (1998), show that higher levels of autonomy (up to a certain level) tend to increase the degree of entrepreneurship of subsidiaries, improving their local marketing performance. However, as pointed out by Oliveira (2009), the quality of the relationship between the parent company and its subsidiaries has to be close in order to maintain the network. Otherwise, subsidiaries might become excessively autonomous or even an independent branch. Therefore, to some extent centralization is important, as discussed by Ferreira, Beltrão, and Almeida (2013).

P8: The better the quality of the relationship between the parent company and its subsidiaries (strength of the internal network), the more important the knowledge flow between the parent company and its subsidiaries (and within subsidiaries) is.

The flow of knowledge can be an important weapon in highly competitive environments if aided by the network approach of business administration (Oliveira, 2009). Subsidiaries usually have better information about the local operation than the $\mathrm{HQ}$ in the country of origin. This issue has been discussed in other arenas since Jensen and Meckling's (1976) agency theory. Therefore, $\mathrm{HQ}$ and subsidiaries should avoid information being distributed asymmetrically (Greenwald; Stiglitz, 1990; Quester; Conduit, 1996; Birkinshaw et al., 1998; Seufert; Von Krogh; Bach, 1999; Oliveira, 2009).

P9: The better the quality of the relationship between the parent company and its subsidiaries (strength of the internal network), the better the subsidiary is at responding to environmental opportunities and changes (local responsiveness):

Access to more knowledge and information through MNC networks not only induces a direct effect on firm performance, but also bolsters the positive effects of strategic marketing postures on firm performance (Lee, 2010). Increases in MNC network strength help the foreign firm obtain more resources from other foreign subsidiaries and its headquarters, reinforcing its responsiveness to local environments (Hansen; Nohria, 2004). In particular, firms with stronger ties are associated with higher levels of trust, facilitating market information exchange (Tsai; Goshal, 1998).

P10: The more autonomy granted to the subsidiary, the more important it is that the subsidiary develops a strong external network.

Previous propositions mentioned the relation between autonomy and business networks. Once a MNC grants autonomy to a subsidiary, it is important to strengthen its value chain (locally and internationally). According to Chiao and Ying (2013), by being closer to the market, a subsidiary can gain sufficient information to understand market characteristics and consumption habits. As a result, the parent firm should grant subsidiaries a higher level of autonomy in order to handle market competition. However, autonomy alone is not sufficient to exploit local opportunities. Subsidiaries need partnerships and a strong external network (Brook, 1984; Gates; Egelhoff, 1986; Bowman et al., 
2000).

P11: The more autonomy granted to the subsidiary, the better the subsidiary is at responding to environmental opportunities and changes (local responsiveness).

Centralization can reduce production costs, improve product quality, and better align strategic programs. However, excessive administration costs and activity concentration in the $\mathrm{HQ}$, can cause delays in decision-making (Oliveira, 2009). Such delays reduce local responsiveness and usually spoil local marketing performance (Birkinshaw et al., 1998; Moore; Birkinshaw, 1998; Bowman et al., 2000). According to Birkinshaw and Morrison (1995), a subsidiary with little autonomy is probably a local implementer, that is, a subsidiary with limited geographic, product, or valued-added scopes. This kind of subsidiary still exists and is necessary in some cases. However, as pointed out by several authors, the role of the subsidiary must gain importance for the MNC to really benefit from it and exploit local opportunities. In order to do so, a marketing prerequisite is that managers effectively understand local needs and desires. In other words, subsidiaries need to become locally embedded for the MNC to obtain maximum results (Birkinshaw et al., 1998; Moore; Birkinshaw, 1998; Taggart; Hood, 1999; Vachani, 1999; Bowman et al., 2000).

P12: The stonger the external network of the subsidiary, the greater its local embeddedness is and the better it is at responding to environmental opportunities and changes (local responsiveness).

The more the subsidiary is rooted in local business networks, the greater the possibilities that the subsidiary gains access to new knowledge that can ensure global competitive advantages (Andersson; Forsgren; Holm, 2002). This means that the subsidiary's external network is related to the degree of its local embeddedness and responsiveness. In order to become a dynamic organization designed to be sensitive to quickly unfolding market events, marketing managers have to try to embed the firm locally. In this sense, according to Achrol (1991), local embedded firms tend to present better marketing performances than other MNC subsidiaries. Marketing orientation should prove to be highly advantageous because it enhances a firm's local responsiveness (Jaworksi; Kohli, 1993). Rugman et al. (2011) also highlight this aspect, suggesting that a firm should understand and manage its outsidership liability rather than deal with its foreignness liability.
Furthermore, according to Frost and Zhou (2000) and Frost (2001), subsidiaries that are involved with local institutions and build relationships with them are characterized as respectable corporations in the country and are accepted as participants in technical and scientific communities abroad. Moore and Birkinshaw (1998) also point out to the issue of local embeddedness as a consequence of a firm's local external network.

P13: The greater the knowledge flow between the parent company and its subsidiaries (and within subsidiaries), the better the subsidiary is at responding to environmental opportunities and changes (local responsiveness).

Knowledge transfer is often associated with the modification of existent knowledge to specific contexts (Foss; Pedersen, 2002). In other words, knowledge transfer is one of the factors that allows the subsidiary to better understand and respond to local dynamics and opportunities. Furthermore, as stated by von Krogh and Köhne (1998), the success of firms in the future will increasingly depend their ability to generate knowledge and to transfer it internally. By seeking market knowledge from its headquarters and other units, a foreign subsidiary may benefit from improving its responsiveness to opportunities and threats arising from its host country, which is important for firm success (Luo, 2001; Roth; Jayachandran; Dakhi; Colton, 2009)

P14: The standardizing/adapting decision exerts influence on the ability of the subsidiary to respond to environmental opportunities and changes (local responsiveness).

Katsikeas, Samiee, and Theodosiou (2006) argue that the effect of standardization on marketing performance becomes stronger if a fit is present between overall marketing program standardization and the market environment in which it is implemented. However, researchers have paid little systematic attention to the conditions other than the environmental fit, which determines when and how standardization is related to firm success (Schilke; Reimann; Thomas, 2009). On the other hand, Theodosiou and Leonidou (2003), for example, demonstrated that there is no direct relationship between standardization and marketing performance, although it influences results. Moreover, as stated by Achrol (1991), the problem of whether to specialize or generalize becomes reduced to whether to develop unique skills that maximize exploitation of an environment and take the risk of 


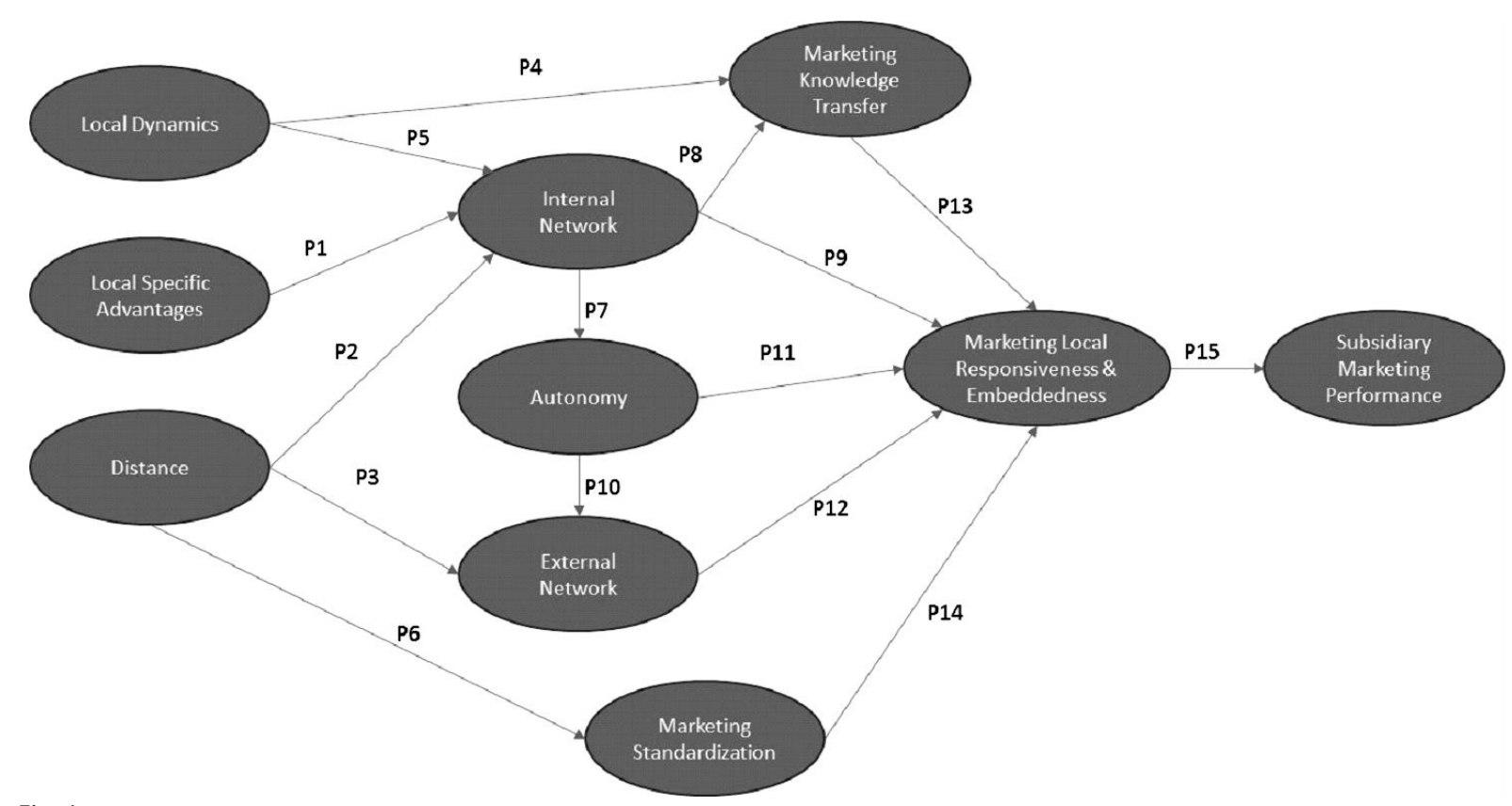

Fig. 1

Integrative model of the marketing performance of subsidiaries Source: Developed by the authors

that environment changing, or accept a lower level of exploitation but one that is feasible for a larger range of environmental states. Therefore, when including a moderating variable, local responsiveness seems accurate for the analysis of the impact of standardization/adaptation on marketing performance.

P15: The greater the ability (skill and speed) of the subsidiary to respond to environmental opportunities and changes (local responsiveness), the better its marketing performance will be:

Jaworski and Kohli (1993) argue that the responsiveness component of a firm is defined as being composed of two sets of activities: i) response design (i.e., using market intelligence to develop plans); and ii) response implementation (i.e., executing such plans). Quick responses to environmental changes have become a vital success factor for today's firms (Homburg; Grozdanovic; Klarmann, 2007). According to Lee et al. (2009), strategy scholars have long suggested that firms that can quickly control and deploy their internal resources in order to act on environmental challenges and opportunities are more likely to obtain better marketing performance. In international marketing, local responsiveness plays the same role, influencing marketing results of subsidiaries.

\subsection{Proposed scales}

Table 1 presents the scales that will be used for the measurement of each of the constructs of the proposed model. All scales and indices were identified in the literature review.

\section{Conclusion}

We believe our work adds to the literature on both international marketing and international business, and adds another element to the growing set of research findings on the marketing performance of subsidiaries operating abroad. The review of the literature offers a new perspective of the main variables related to this issue: i) local characteristics (psychic distance and environmental turbulence); ii) degree of centralization and autonomy; iii) degree of standardization and adaptation; iv) The subsidiaryheadquarters relationship (knowledge transfer and internal and external networks); and v) local embeddedness and responsiveness.

Furthermore, by means of the proposed integrative model, it is possible to incorporate the context of operations and the dynamics of specific markets into analysis. These aspects help not only managers in evaluating their firms, but also offers a more robust mindset when developing international marketing strategies. Thus, the proposed model permits the expansion of theory in International Business and in International Marketing. 
Tab. 1

Constructs and proposed scales

\begin{tabular}{ll}
\hline \multicolumn{1}{c}{ Construct } & \multicolumn{1}{c}{ Definition and Scales } \\
\hline Location-Specific Advantage & $\begin{array}{l}\text { Country risk index (international country risk - ICR - PRS Group); GDP per capita (World } \\
\text { Bank); economic freedom index (DE BEULE; ELIA; PISCITELLO, 2014); Melo et al. (2015) }\end{array}$ \\
\hline Local Dynamics & $\begin{array}{l}\text { Ease of doing business (EDB - World Bank); Gini index; Eroglu (1992); Jaworski, Kohli (1993); } \\
\text { Alon, Shohan (2010); Melo et al. (2015) }\end{array}$ \\
\hline Distance & Hofstede's distance index; governance indicators (World Bank); inflation rate; median age \\
& of population; Chiao, Lo, Yu (2010); Cui et al. (2014) \\
\hline Internal Network & Jaworski, Kohli (1993); Lee (2010); Lamprinopoulou, Tregear (2011) \\
\hline Marketing Knowledge Transfer & Lee, Chen, Lu (2009); Rocha (2009); Rocha, Borini, Spers, Khauaja, Camargo (2012); Rocha, \\
& Borini, Spers, Ogasavara, Khauaja, Camargo, Melo (2014); Schleimer, Coote, Riege (2014); \\
\hline Autonomy & Park et al. (2013) \\
\hline External Network and & Jaworski, Kohli (1993); Zou, Cavusgil (2002); Homburg, Prigge (2014) \\
Embeddedness & Polanyi (1944); Uzzi (1997); Lee (2010); Cretoiu, Barakat, Ximenes, Alvim, Neves (2010); \\
\hline Marketing Standardization & Lamprinopoulou, Tregear (2011) \\
\hline Local Marketing Responsiveness & Jain (1989); Quester, Conduit (1996); Zou, Cavusgil (2002); Vrontis et al. (2009) \\
\hline Subsidiary Marketing Performance & Jaworski, Kohli (1993); Lee et al. (2009); Lee (2010) \\
& Townsend, Yeniyurt, Deligonul, Cavusgil (2004); Schilke et al. (2009); Grewal et al. (2009); \\
\hline
\end{tabular}

Source: Organized by the authors

Concerning managerial contributions, the proposed model might be useful for the determination of the variables that affect marketing performance in subsidiaries. Furthermore, it can assist marketing managers in the understanding of the results from the analysis of measurable and known variables. The model summarizes the main variables that can affect marketing performance. In terms of a rationale, it is ready to use. Its validation is needed to ascertain cause-and-effect relationships.

For future studies we recommend secondary data research, using existing data from MNCs and even official reports and databases. A survey with marketing managers of subsidiaries operating abroad is important as well. By creating a robust and reliable database, it is possible to perform statistical analysis and validate the model proposed. Since any measure often reflects not only a theoretical concept of interest but also measurement errors (Bagozzi; Yi; Phillips, 1991), it is highly recommended that the researcher verifies the reliability and the validity of the model, the variables, and their relationship.

We suggest the development of both a confirmatory factor analysis and a discriminant analysis in order to determine which propositions can be gathered. Once the propositions are determined, they can be evaluated through structural equation modeling and their relationships can be arbitratedthat is, causality, mediation (full or partial), moderation. We propose the use of structural equations because they are especially useful for testing theories containing multiple equations that involve dependency relationships (Hair et al., 2010).

\section{References}

- ACHROL, R. S. Evolution of the Marketing Organization: New Forms for Turbulent Environments. Journal of Marketing, v. 55, p. 77-93, 1991.

- ALON, I.; SHOHAM, A. Clustering for international market selection. Franchise globally: Innovation, learning and imitation, 73-90, 2010.

- ambeV fecha fábrica na VEnEzUela, mas aINDA VENDERÁ PRODUTOS EM PARCERIA. Disponível em: <http://economia.uol.com.br/noticias/afp/2013/03/20/ ambev-abandona-venezuela-diante-de-situacaoinviavel.htm>. Acesso em: 10 out. 2016.

- AMBOS, T. C.; AMBOS, B.; SCHLEGELMILCH, B. B. Learning from foreign subsidiaries: An empirical investigation of headquarters' benefits from reverse knowledge transfer. International Business Review, v. 15, p. 294-312, 2006.

- ANDERSSON, U.; FORSGREN, M.; HOLM, U. The strategic impact of external networks: Subsidiary performance and competence development in the multinational corporation. Strategic Management Journal, v. 23, n. 11, p. 979-996, 2002.

- BABIN, B. J.; HAIR JR, J. F.; BOLES, J. S. Publishing research in marketing journals using structural equation modeling. Journal of Marketing Theory \& Practice, v. 16, n. 4, p. 279-285, 2008.

- $\quad$ BACKHAUS, K.; VAN DOORN, J. Consumer perceptions of advertising starndardisation: a cross-country study of different advertising categories. International 
Management Review, v. 3, n. 4, p. 37-53, 2007.

- $\quad$ BAGOZZI, R. P.; YI, Y.; PHILLIPS, L. W. Assessing Construct Validity in Organizational Research. Administrative Science Quarterly, v. 36, n. 3, p. 421-458, 1991.

- $\quad$ BAKER, W. E.; SINKULA, J. M. Environmental marketing strategy and firm performance: effects on new product performance and market share. Journal of the Academy of Marketing Science, v. 33, n. 4, p. 461-475, 2005.

- BARTLETT, C. A.; GHOSHAL, S. Managing across borders. Boston, MA: Harvard University Press, 1989.

- BIRKINSHAW, J.; HOOD, N.; JONSSON, S. Building firmspecific advantages in multinational corporations: The role of subsidiary initiative. Strategic Management Journal, v. 19, n. 3, p. 221-242, 1998.

- _ _ HOLM, U.; THILENIUS, P.; ARVIDSSON, N. Consequences of Perception Gaps in the HeadquartersSubsidiary Relationship. International Business Review, v. 9, n. 3, p. 321-344, 2000.

- BOWMAN, S.; DUNCAN, J.; WEIR, C. Decision-making autonomy in multinational corporation subsidiaries operating in Scoltland. European Business Review, v. 12, n. 2, p. 129-136, 2000.

- BROOK, M. Z. Centralization and autonomy: A study in organization behavior. London: Holt, Rinehart and Winston, 1984.

- CATEORA, P. R.; GRAHAM, J. L. International Marketing. Estados Unidos: McGraw-Hill, 1999.

- CAVUSGIL, S. T.; ZOU, S. Marketing StrategyPerformance Relationship: An Investigation of the Empirical Link in Export Market Ventures. Journal of Marketing, v. 58, n. 1, p. 1-21, 1994.

- CHIAO, Y. C.; LO, F. Y.; YU, C. M. Choosing between wholly-owned subsidiaries and joint ventures of MNCs from an emerging market. International Marketing Review, v. 27, n. 3, p. 338-365, 2010.

- _ _ _ Y YING, K. P. Network effect and subsidiary autonomy in multinational corporations: An investigation of Taiwanese subsidiaries. International Business Review, v. 22, n. 4, p. 652-662, 2013.

- CHURCHILL JR, G. A. A Paradigm for Developing Better Measures of Marketing Constructs. Journal of Marketing Research, v. 16, n. 1, p. 64-73, 1979.

- COlTMAN, T.; DEVINNEY, T. M.; MIDGLEY, D. F.; VENAIK, $S$. Formative versus reflective measurement models: two applications of formative measurement. Journal of Business Research, v. 61, n. 12, p. 1250-1262, 2008.

- costa, L. H. I. Internacionalização de empresas e adaptação do mix de marketing: um estudo de caso no Mercosul. Rio de janeiro: COPPEAD/UFRJ, 1998.

- CRAIG, C. S.; DOUGLAS, S. P. Configural advantage in global markets. Journal of International Marketing, v. 8, n. 1, p. 6-26, 2000.

- CUI, A. S.; GRIFFITH, D. A.; CAVUSGIL, S. T.; DABIC, M. The Influence of Market and Culture Environmental
Factors on Technology Transfer Between Foreign MNCs and Local Subsidiaries: A Croatian Illustration. Journal of World Business, v. 41, n. 2, p. 100-111, 2006.

- CUI, A. P.; WALSH, M. F.; ZOU, S. The Importance of Strategic Fit Between Host-Home Country Similarity and Exploration Exploitation Strategies on Small and Medium-Sized Enterprises' Performance: A Contingency Perspective. Journal of International Marketing, v. 22, n. 4, p. 67-85, 2014.

- DALMORO, M. Estratégias de Marketing Internacional e a Relação com a Performance Exportadora e Orientação para Mercado Externo. Internext, v. 4, n. 2, p. 1-18, 2010.

- DE BEULE, F.; ELIA, S.; PISCITELLO, L. Entry and access to competencies abroad: emerging market firms versus advanced market firms. Journal of International Management, v. 20, n. 2, p. 137-152, 2014.

- CARPes, A. M.; Velter, A. N.; SCherer, F. L.; LÜTZ, C. Panorama internacional das publicações em International Business: levantamento por meio da base Web of Science. Internext, v. 5, n. 2, p. 117-139, 2010.

- diamantopoulos, A.; SINGUAW, J. A. Formative versus reflective indicators in organizational measure development: a comparison and empirical illustration. British Journal of Management, v. 17, n. 4, p. 263-282, 2006.

- DOMINGUES, F. Danone e Nestlé anunciam fechamento de unidade de lácteos na China, 2011. Disponível em: <http://www.canalrural.com.br/noticias/pecuaria/dano ne-nestle-anunciam-fechamento-unidade-lacteoschina-3467>. Acesso em: 18 out. 2016.

- DUNNING, J. H. Toward an eclectic theory of international production: some empirical tests. Journal of International Business Studies, p. 11, n. 1, p. 9-31, 1980.

- The eclectic paradigm of international production: a restatement and some possible extensions. Journal of International Business Studies, p. 1-31, 1988.

- The theory of translational corporations. London: Routledge, 1993.

- EDWARDS, J. R. Multidimensional constructs in organizational behavior research: An integrative analytical framework. Organizational Research Methods, v. 4, n. 2, p. 144-192, 2001.

- $\quad$ EROGLU, S. The internationalization process of franchise systems: a conceptual model. International Marketing Review, v. 9, n. 5, 1992.

- FATT, A. The danger of local international advertising. Journal of Marketing, p. 31, n. 1, p. 60-62, 1967.

- CRETOIU, S. L.; BARAKAT, L.; XIMENES, M.; ALVIM, F. M.; NEVES, I. Ranking das Transnacionais Brasileiras 2011: crescimento e gestão sustentável no exterior. FDC Fundação Dom Cabral, 2011.

- ferreira, M. P.; Beltrão, J. S.; AlmeidA, M. R. Relações de controle e autonomia entre multinacionais 
e subsidiárias: um estudo de caso de multinacional norte-americana em Portugal. Internext, v. 8, n. 3, p. 2037, 2013.

- ferrell, O. C.; HARTLine, M. D. Estratégia de Marketing. São Paulo: Cengage Learning Editores, 2009.

- FORNELL, C.; LARCKER, D. F. Structural Equation Models with Unobservable Variables and Measurement Error: Algebra and Statistics. Journal of Marketing Research, v. 18, n. 3, p. 382-388, 1981.

- FOSS, N. J.; PEDERSEN, T. Transferring knowledge in MNCs: The role of sources of subsidiary knowledge in organizational context. Journal of International Marketing, v. 8, n. 1, p. 49-67, 2002.

- $\quad$ FROST, T. The geographic sources of foreign subsidiaries innovation. Strategic Management Journal, v. 22, p. 10113, 2001.

- __ _ _ ZHOU, C. The geography of foreign R\&D within a host country: An evolutionary perspective on locationtechnology selection by multinationals. International Studies of Management \& Organizations, p. 10-43, 2000.

- gates, S. R.; EgelhofF, W. G. Centralization in headquarters-subsidiary relationships. Journal of International Business Studies, v. 17, n. 2, p. 71-92, 1986.

- greenwald, B. C.; StiglitZ, J. E. Asymmetric information and the new theory of the firm: financial constraints and risk behavior. American Economic Review, v. 80, n. 2, p. 160-165, 1990.

- GREWAL, D.; IYER, G. R.; KAMAKURA, W. A.; MEHROTRA, A.; SHARMA, A. Evaluation of subsidiary marketing performance: combining process and outcome performance metrics. Journal of the Academy of Marketing Science, v. 37, p. 117-129, 2009.

- haIR JR, J. F.; BLACK, W. C.; BABIN, B. J.; ANDERSON, R. E. Multivariate Data Analysis. 7th ed. Upper Saddle River: Prentice Hall, 2010.

- HANSEN, M. T.; NOHRIA, N. Organizing Multinational Companies for Collaborative Advantage. In: QUELCH, J.; DESHPANDÉ, R. (Eds.). The Global Market: Developing a Strategy to Manage Across Borders. San Francisco: John Wiley \& Sons, p. 92-112, 2004.

- HOFSTEDE, G. Culture's consequences. Beverly Hills, 1980.

- HOLM, U.; PEDERSEN, T. The Emergence and Impact of MNC Centres of Excellence: a subsidiary perspective. London: McMillan Press, 2000

- HOMBURG, C.; PFLESSER, C. A Multiple-Layer Model of Market-Oriented Organizational Culture: Measurement Issues and Performance Outcomes. Journal of Marketing Research, v. 37, n . 4, p. 449-462, 2000.

GROZDANOVIC, M.; KLARMANN, M. Responsiveness to Customers and Competitors: The Role of Affective and Cognitive Organizational Systems. Journal of Marketing, v. 71, n. 3, p. 18-38, 2007.

$\cdot$ PRIGGE, J. Exploring Subsidiary Desire for
Autonomy: A Conceptual Framework and Empirical Findings. Journal of International Marketing, v. 22, n. 4, p. 21-43, 2014.

- HUTSChENREUTER, T.; KLEINDIENST, I.; LANGE, S. The Concept of Distance in Internacional Business Research: A Review and Research Agenda. International Journal of Management Review, p. 1-20, 2015.

- JAIN, S. C. Standardization of International Marketing Strategy: Some Research Hypotheses. Journal of Marketing, v. 53, p. 70-79, 1989.

- JARVIS, C. B.; MACKENZIE, S. B.; PODSAKOFF, P. M. A Critical Review of Construct Indicators and Measurement Model Misspecification in Marketing and Consumer Research. Journal of Consumer Research, v. 30, n. 2, p. 199-218, 2003.

- JAWORSKI, B. J.; KOHLI, A. K. Market Orientation: Antecedents and Consequences. Journal of Marketing, v. 57, p. 53-70, 1993.

- JENSEN, M. C.; MECKLING, W. H. Theory of the firm: managerial behavior, agency costs and ownership structures. Journal of Financial Economics, v. 3, n. 4, p. 305-360, 1976.

- JOHANSON, J.; VAHLNE, J. E. The internationalization process of the firm-a model of knowledge development and increasing foreign market commitments. Journal of international business studies, p. 23-32, 1977.

- $;$ WIEDERSHEIM-PAUL, F. The internationalization of the firm - four Swedish cases. Journal of Management Studies, v. 12, p. 305-322, 1975.

- KASHANI, K. Beware of pitfalls of global marketing. Harvard Business Review, September/October, v. 67, n. 5, p. 91-98, 1989.

- $\quad$ KATSIKEAS, C. S.; SAMIEE, S.; THEOdOSIOU, M. Strategy fit and performance consequences of international marketing standardization. Strategic Management Journal, v. 27, n. 9, p. 867-890, 2006.

- KEEgAN, W. J. Marketing Global. São Paulo: Pearson Prentice Hall, 2005.

- KITCHEN, P. J. The Rhetoric and Reality of Marketing: An International Managerial Approach, PalgraveMacmillan, Basingstoke, 2003.

- KOGUT, B.; SINGH, H. The effect of national culture on the choice of entry mode. Journal of International Business Studies, v. 19, n. 3, p. 411-432, 1988.

- LAMBIN, J. J. Marketing Estratégico. São Paulo: McGrawHill, 2000.

- $\quad$ LAMPRINOPOULOU, C.; TREGEAR, A. Inter-firm relations in SME clusters and the link to marketing performance. Journal of Business \& Industrial Marketing, v. 26, n. 6, p. 421-429, 2011.

- LEE, R. P. Extending the Environment-StrategyPerformance Framework: The roles of multinational corporation network strength, market responsiveness, and product innovation. Journal of International Marketing, v. 18, n. 4, p. 58-73, 2010. 
$\cdot$ Transfer Headquarters and Their Subsidiaries: Influences on and Implications for New Product Outcomes. Journal of International Marketing, v. 16, n. 2, p. 1-31, 2008.

; LU, X. In Search of Platforms to Increase Market Responsiveness: Evidence from Foreign Subsidiaries. Journal of International Marketing, v. 17, n. 2, p. 59-73, 2009.

- LEONIDOU, L. C.; BARNES, B. R.; KATSIKEAS, S. S. Assessing the contribution of leading mainstream marketing journals to the international marketing discipline. International Marketing Review, v. 27, n. 5, p. 491-518, 2009.

- LEVITT, T. The globalization of markets. Harvard Business Review, v. 61, p. 92-102, 1983.

- LUO, Y. Determinants of Local Responsiveness: Perspectives from Foreign Subsidiaries in an Emerging Market. Journal of Management, v. 27, n. 4, p. 451-477, 2001.

- C. Capability exploitation and building in a foreign market: Implications for multinational enterprises. Organization Science, v. 13, p. 48-63, 2002.

- MACKENZIE, S.; PODSAKOFF, P.; JARVIS, C. The problem of measurement model misspecification in behavioural and organizational research and some recommended solutions. Journal of Applied Psychology, v. 90, n. 4, p. 710-730, 2005.

- Martin, I. M.; EROglU, S. Measuring a MultiDimensional Construct: Country Image. Journal of Business Research, v. 28, p. 191-210, 1993.

- MATHEWS, J. Dragon Multinationals. Oxford: Oxford University Press, 2002.

- . Response to Dunning and Narula, 2016. Disponível em: <http://www.baf.cuhk.edu.hk/asiaaom/APJM/Mathews\%20\%20Response\%2023.2.pdf>. Acesso em: 05 mar. 2015.

- MATSUnO, K.; MENTZER, J. T. The effects of strategy type on the market orientation-performance relationship. Journal of Marketing, v. 64, n. 4, p. 1-16, 2000.

- MELO, P. L. R.; BORINI, F.; OLIVEIRA JR, M. M.; PARENTE, $R$. International analysis of the countries in which Brazilian franchise chains operate. Revista de Administração da USP, v. 50, n. 1, p. 26-39, 2015.

- MENON, A.; BHARADWAJ, S. G.; ADIDAM, P. T.; EDISON, S. W. Antecedents and Consequences of Marketing Strategy Making: A Model and a Test. Journal of Marketing, v. 63, p. 18-40, 1999.

- MOORE, K.; BIRKINSHAW, J. Managing knowledge in global service firms: centers of excellence. The academy of Management executive, v. 12, n. 4, p. 81-92, 1998.

- NAVES, P. Rede de fast food Arby's fecha suas 21 lojas próprias em SP, 1999. Disponível em: <http://www1.folha.uol.com.br/fsp/tudo/ct241019991 3.htm>. Acesso em: 20 de set. de 2016.
- NeTEMEYER, R. G.; BEARDEN, W. O.; SHARMA, S. Scaling procedures. CA: Sage, 2003.

- Oliveira JR, M. M. Internacionalização de empresas brasileiras: o papel das subsidiárias (Full Professor Dissertation, Faculdade de Economia, Administração e Contabilidade, Universidade de São Paulo), 2009.

- $\quad$ PARK, C.; VERTINSKY, I.; BECERRA, M. Transfer of tacit vs. explicit knowledge and performance in international joint ventures: The role of age. International Business Review, v. 24, p. 89-101, 2015.

- PESSOA, C. O.; ROCHA, A. Levando o Brasil para fora: comidas brasileiras da China e das Arábias. In: ROCHA, A. (Ed.). As novas fronteiras: a multinacionalização das empresas brasileiras. Rio de Janeiro: Mauad, 2003, p. 77-101.

- $\quad$ Peter, J. P. Construct Validity: A Review of Basic Issues and Marketing Practices. Journal of Marketing Research, v. 18, n. 2, p. 133-145, 1981.

- $\quad$ PHILIPS, C.; DOOLE, I.; LOWE, R. International Marketing Strategy. Londres: Routledge, 1994.

- PIPKIN, A. Marketing internacional: uma abordagem estratégica. São Paulo: Aduaneiras, 2005.

- POLANYI, K. The great transformation: The political and economic origins of our time. Beacon Press, 1944.

- Quester, P. G.; CONDUit, J. Standardization, centralization and marketing in multinational companies. International Business Review, v. 5, n. 4, p. 395-421, 1996.

- $\quad$ RAMAMURTI, R. What have we learned about emergingmarket MNEs? In: RAMAMURTI, R.; SINGH, J. V. (Eds.), Emerging multinationals from emerging markets, Cambridge: Cambridge University Press, 2009, p. 399426.

- What is really different about emerging market multinationals? Global Strategy Journal, v. 2, p. 41-47, 2012.

- RAMOS, M. C. A internacionalização não é uma opção, é uma necessidade, 2011. Disponível em: < https://www.google.com.br/url?sa=t\&rct=j\&q=\&esrc=s \&source $=$ web \& $c d=2 \& c a d=r j a \& u a c t=8 \&$ ved $=0$ ahUKEwj Qren8qOzPAhVJiZAKHX4eDkIQFggjMAE\&url=http\%3A\% 2F\%2Fwww.ordemengenheiros.pt\%2Fpt\%2Fcentro-deinformacao\%2Fimprensa\%2Foe-nos-media\%2Fainternacionalizacao-nao-e-uma-opcao-e-umanecessidade\%2F\&usg=AFQjCNHsNv6k6HLe9whJ6bk5hZly-hvog>. Acesso em: 21 out. 2016.

- REINARTZ, W.; KRAFFT, M.; HOYER, W. D. The customer relationship management process: Its measurement and impact on performance. Journal of Marketing Research, v. 41, n. 3, p. 293-305, 2004.

- ROCHA, T. V. Transferência de Conhecimento sobre Marketing em Corporações Multinacionais: Estudo em Subsidiárias Brasileiras. In: AMATUCCI, M. Internacionalização de empresas: teorias, problemas e casos, 2009, p.179-202.

- $\quad$ _ $\quad$ B BORINI, F. M.; SPERS, E. E.; KHAUAJA, D.; 
CAMARGO, A. Aspectos mercadológicos e estratégicos da internacionalização de franquias brasileiras. São Paulo: ESPM, 2012.

$\cdot$ ; OGASAVARA, M. H.; KHAUAJA, D.; CAMARGO, A.; MELO, P. L. R. Stages of Internationalization of Brazilian Franchises. São Paulo: ESPM, 2014

- ROTH, M. S.; JAYACHANDRAN, S.; DAKHI, M.; COLTON, D. A. Subsidiary Use of Foreign Marketing Knowledge. Journal of International Marketing, v. 17, n. 1, p. 1-29, 2009.

- Rugman, A. M. New theories of multinationals enterprises: an assessment of internationalization theory. Bulletin of Economic Research, v. 38, p. 101-118, 1986.

- _ _ VERBEKE, A.; NGUYEN, Q. Fifty years of international business theory and beyond. Management International Review, v. 51, p. 755-786, 2011

- RUST, R. T.; LEMON, K. N.; ZEITHAML, V. A. Return on marketing: Using customer equity to focus marketing strategy. Journal of Marketing, v. 68, n. 1, p. 109-127, 2004.

- SCHILKE, O.; REIMANN, M.; THOMAS, J. S. When Does International Marketing Standardization Matter to Firm Performance?. Journal of International Marketing, v. 17, n. 4, p. 24-46, 2009.

- SCHLEGELMILCH, B. B.; CHINI, T. C. Knowledge transfer between marketing functions in multinational companies: a conceptual model. International Business Review, v. 12, n. 2, p. 215-232, 2003.

- SCHLEIMER, S. C.; COOTE, L. V.; RIEGE, A. Headquarters to subsidiary transfer effects on marketing strategy exploitation. Journal of Business Research, v. 67, p. 307315, 2014

- SCHMID, S.; KOTULLA, T. 50 years of research on international standardization and adaptation - From a systematic literature analysis to a theoretical framework. International Business Review, v. 20, p. 491507, 2011.

- SEUfert, A.; VON KROGH, G.; BACH, A. Towards knowledge networking. Journal of Knowledge Management, v. 3, n. 3, p. 180-190, 1999.

- SHENKAR, O.; LUO, Y.; YEHESKEL, O. From 'distance' to 'friction': substituting metaphors and redirecting intercultural research. Academy of Management Review, v. 33, p. 905-923, 2008.

- SOUFANI, K.; VRONTIS, D.; POUTZIOURIS, P. Private equity for small firms: a conceptual model of adaptation versus standardization strategy. International Journal of Entrepreneurship and Small Business, v. 3, n. 3/4, p. 498515, 2006

- SOUSA, C. M.; LENGLER, J. Psychic distance, marketing strategy and performance in export ventures of Brazilian firms. Journal of Marketing Management, v. 25, n. 5/6, p. 591-610, 2009.

- SYZMANSKI, D. M.; BHARADWAJ, S. G.; VARADARAJAN,
P. R. Standardization versus adaptation of international marketing strategy: An empirical investigation. Journal of Marketing, v. 57, p. 1-17, 1993.

- TABACHNICK, B. G.; FIDELL, L. S. Experimental Design Using ANOVA. Belmont: Thomson Higher Education, 2007

- TAGGART, J. H.; HOOD, N. Determinants of autonomy in multinational corporation subsidiaries. European Management Journal, v. 17, n. 2, p. 226-236, 1999.

- TheOdosiou, M.; LEONIDOU, L. C. Standardization versus adaptation of international marketing strategy: an integrative assessment of the empirical research. International Business Review, v. 12, p. 141-171, 2003.

- thrassou, A.; VRONTIS, D. A small services firm marketing communications model for SME-dominated environments. Journal of Marketing Communications, v. 12, n. 3, p. 183-202, 2006.

- TOWNSEND, J. T.; ASHBY, F. G. Measurement Scales and Statistics: The Misconception Misconceived. Psychological Bulletin, v. 96, n. 2, p. 394-401, 1984

- TOWNSEND, J. D.; YENIYURT, S.; DELIGONUL, Z. S.; CAVUSGIL, S. T. Exploring the Marketing Program Antecedents of Performance in a Global Company. Journal of International Marketing, v. 12, n. 4, p. 1-24, 2004.

- TSAI, W.; GHOSHAL, S. Social Capital and Value Creation: The Role of Intrafirm Networks. Academy of Management Journal, v. 41, n. 4, p. 464-476, 1998.

- UZZI, B. Social structure and competition in interfirm networks: The paradox of embeddedness. Administrative Science Quarterly, v. 42, n. 1, p. 35-67, 1997.

- VACHANI, S. Global diversification's effect on multinational subsidiaries' autonomy. International Business Review, v. 8, n. 3, p. 535-560, 1999.

- VERMEULEN, F.; BARKEMA, H. Pace, rhythm, and scope: process dependence in building a profitable multinational Corporation. Strategic Management Journal, v. 23, p. 637-653, 2002.

- VERNON, R. The product cycle hypothesis in a new international environment. Oxford bulletin of economics and statistics, v. 41, n. 4, p. 255-267, 1979.

- VON KROGH, G.; KÖHNE, M. Der Wissenstransfer in Unternehmen: Phasen des Wissenstransfers und wichtige Einflussfaktoren. Die Unternehmung, v. 52, n. 5/6, p. 235-252, 1998

- VORHIES, D. W.; MORGAN, N. A. A configuration theory assessment of marketing organization fit with business strategy and its relationship with marketing performance. Journal of Marketing, v. 67, n. 1, p. 100115, 2003.

- VRONTIS, D. Integrating adaptation and standardisation in international marketing, the AdaptStand modelling process. Journal of Marketing Management, v. 19, n. 3/4, p. 283-305, 2003 
- _ _ _ _ THRASSOU, A.; LAMPRIANOU, I. International marketing adaptation versus standardisation of multinational companies. International Marketing Review, v. 26, n. 4/5, p. 477-500, 2009.

- $\quad X U$, S.; CAVUSGIL, S. T.; WHITE, J. C. The impact of strategic fit among strategy, structure and processes on multinational corporation performance: A multimethod assessment. Journal of International Marketing, v. 14, n. 2, p. 1-31, 2006.

- YIP, G. Toward a new global strategy. Chief Executive Journal, v. 110, p. 66-67, 1996.
- YOUNG, S.; TAVARES, A. T. Centralization and autonomy: Back to the future. International Business Review, v. 13, n. 2, p. 215-237, 2004.

- ZAHEER, S.; SHOMAKRE, M. S.; NACHUM, L. Distance without direction: restoring credibility to a much-loved constructo. Journal of International Business Studies, v. 43, p. 18-27, 2012.

- ZOU, S.; CAVUSGIL, S. T. The GMS: A broad conceptualization of global marketing strategy and its effect on firm performance. Journal of Marketing, v. 66, p. 40-56, 2002.

\section{About the authors}

- Roberto Flores Falcão is Professor at FEA/USP, Brazil. E-mail: titofalcao@usp.br

- Gilmar Masiero is Professor at FEA/USP, Brazil.E-mail: gilmarmasiero@usp.br

- Marcos Campomar is Professor at FEA/USP, Brazil.E-mail: campomar@usp.br

To cite this article:

Falcão, R. F.; Masiero, G. and Campomar, M. (2016) Marketing performance of subsidiaries operating abroad: An integrative model. Internext - Revista Eletrônica de Negócios Internacionais, 11 (3), 64-77. DOI: 10.18568/1980-4865.11364-77

To access this article: $h t t p: / / d x . d o i . o r g / 10.18568 / 1980-4865.11364-77$ 